OPEN ACCESS

Edited by:

Chan Wang,

Guangdong University of Finance and

Economics, China

Reviewed by:

Chen Ziyue,

Norwegian University of Science and

Technology, Norway

Yi Fu,

Central South University, China

${ }^{*}$ Correspondence:

Dong-Xiao Yang

ydx622@hutb.edu.cn

Specialty section:

This article was submitted to

Sustainable Energy Systems and

Policies,

a section of the journal

Frontiers in Energy Research

Received: 31 January 2021

Accepted: 18 February 2021

Published: 29 April 2021

Citation:

Qiu L-S, Yang D-X, Hong K-R, Wu W-P and Zeng $W-K$ (2021) The Prospect of China's Renewable Automotive

Industry Upon Shrinking Subsidies.

Front. Energy Res. 9:661585.

doi: 10.3389/fenrg.2021.661585

\section{The Prospect of China's Renewable Automotive Industry Upon Shrinking Subsidies}

\author{
Lin-Shu Qiu ${ }^{1}$, Dong-Xiao Yang ${ }^{2,3 *}$, Kai-Rong Hong ${ }^{1}$, Wei-Ping $W^{2,3}$ and Wei-Kang Zeng ${ }^{2}$ \\ ${ }^{1}$ Business School, Central South University, Changsha, China, ${ }^{2}$ Key Laboratory of Digital Economy and High Quality \\ Development, Hunan University of Technology and Business, Changsha, China, ${ }^{3}$ School of Econimics and Trade, Hunan \\ University, Changsha, China
}

Increased emissions from road traffic resulting from the increase in car ownership have put enormous pressure on China's environmental problems. To solve this problem, the Chinese government has attached great importance to the development of a new energy vehicle industry. This paper summarizes the incentive policies of China's new energy vehicle industry. By sorting through the incentive policy system of the new energy vehicle industry, we find that the Chinese government's promotion policy for the new energy vehicle industry is a process of gradual transformation from being government-led to being market-led. In this process, with the decrease of the subsidy amount, it is bound to cause a huge impact on the new energy vehicle industry.

Keywords: renewable automotive, subsidy, policy system, shrink, review

\section{INTRODUCTION}

The automotive industry is a pillar industry of China's national economy and social development. In the past decade or so, driven by rapid economic development and accelerated urbanization, the car parc as well as production in China has increased dramatically. In the past 25 years, the total number of vehicles in China has increased 26 times (Wu and Zhang, 2017). In accordance with the practice of developed countries, the rapid growth of vehicle sales in China is likely to continue in the coming years as a result of rigid demand and consumption upgrades.

With a population of about 1.4 billion, energy shortages and environment issues would become more prominent as the sales of vehicles grows. The International Energy Agency (IEA) reported that China's road transportation sector has discharged 618 million tons of carbon dioxide emissions (International Energy Agency, 2015), accounting for more than 10\% of the total emissions in China and approximately $2 \%$ of the global fossil fuel emissions, respectively. If the car parc continues to grow at its current rate, the total carbon dioxide emissions generated from transportation may reach 12 to 17 billion tons by 2030 (He et al., 2005; Yan and Crookes, 2009; Huo and Wang, 2012). To solve the problems of energy shortage and pollution, accelerating the development of green vehicles has become extremely important.

Xi Jinping, general secretary of the Communist Party of China, proposed in 2014 that the development of new energy vehicles was the only way out for the auto industry. This has been raised in meetings and important speeches, showing that speeding up the cultivation and development of new energy vehicles, can, not only effectively reduce the pressure on energy and the environment, but is also a solution to the people of China's yearning for a better life environment and is an important measure of the contradiction of environmental degradation. With the help of policy, China's new energy vehicle market has become the fastest growing market in the world. However, with the decline 


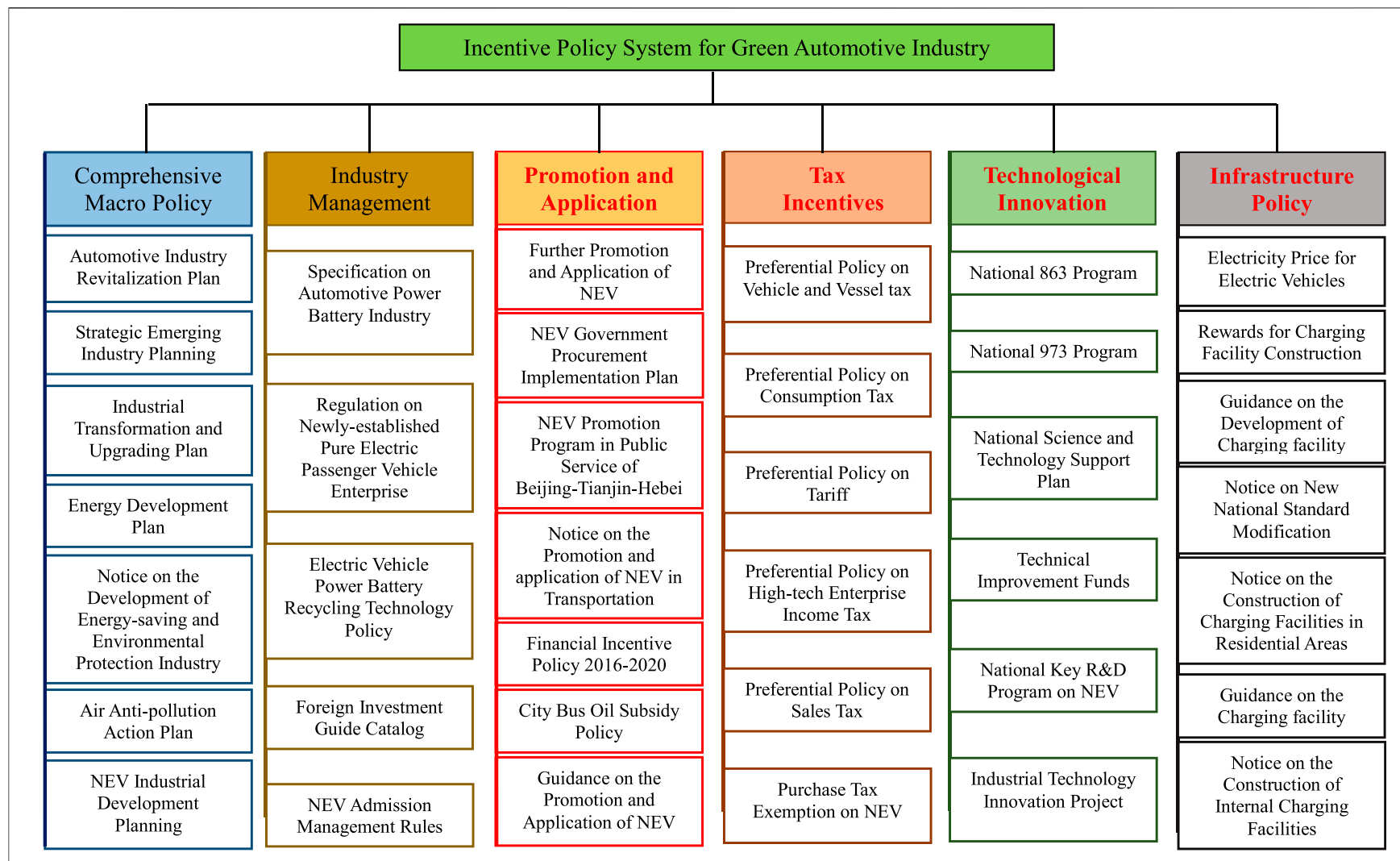

FIGURE 1 | Incentive policy system for green automotive industry.

in subsidies, how should new energy vehicle enterprises face the "greenhouse" and "post-subsidy" era? How will they have to change to survive? How will new industrial incentive policies be decided in the future? It has clearly become a topic of practical significance. Based on this, this paper takes a systematic look at the promotion policies of China's new energy vehicle industry and puts forward policy suggestions for the development path of China's new energy vehicle policy.

\section{THE CARDING OF POLICY PATH}

As shown in Figure 1, China has formulated a comprehensive policy system for green vehicles, including macro-economic integration, industry management, tax incentives, technological innovation, promotion and application, and infrastructure.

At its initial stage, the development of the green automotive industry is dominated by the government, mainly reflected by the demonstration and promotion of green vehicles in large and medium-sized cities. In 2001, relying on the National High-tech R\&D Program (863 Program), the electric vehicles project was launched, and the industrial distribution characterized as "Three Longitudinal Axes and Three Transverse Axes" was established. Specifically, "Three Longitudinal Axes" refer to hybrid vehicles, pure electric vehicles, and fuel cell vehicles, and "Three Transverse Axes" refer to the multi-energy powertrain control system, motor control system, and the battery management system. Between 2001 and 2008, China launched a series of industrial policies to encourage automotive technology to be energy-saving, environmentally friendly, and sustainable. The government proposed that the percentage of electric vehicles in the car parc should be $5-10 \%$ by 2010 and more than $50 \%$ by 2030 .

Due to the 863 Program, green vehicle technology innovations emerged in large numbers. In particular, during the "Eleventh Five-Year Plan" period, China implemented Green Vehicle Major Projects, focusing on the R\&D activities related to the improvement of power systems and key components of green vehicles. Great progress has been achieved in technical standards, testing techniques, demonstration operations, etc. China's electric vehicle industry grew from scratch as the technology systems were gradually established, issuing 56 national standards and more than 3,000 patents. Some of the representative demonstration projects were shown at the Beijing Olympics, the Shanghai World Expo, and the Shenzhen Universiade.

Based on practical experience, it is rational to expect that purely electric-driven vehicles instead of conventional hybrid vehicles would be the major development trend of electric vehicles. Relying on appropriate technical routes, guidance and planning, a lot of leading R\&D projects have been completed as expected. There is no doubt that the outputs of such research projects significantly improve the development of green vehicles, whereas there is still a large gap between the achievement and the demand of the industrialization. The existence of such a gap 
TABLE 1 | A summary of subsidy policies for green vehicles in China.

\begin{tabular}{ll}
$\begin{array}{l}\text { Issued } \\
\text { time }\end{array}$ & \multicolumn{1}{c}{ Document title } \\
\hline $1 / 23 /$ & $\begin{array}{l}\text { Notice on launching pilot programs for the } \\
\text { demonstration and promotion of energy-saving and } \\
2009\end{array}$ \\
& green vehicles
\end{tabular}

$5 / 31 /$

2010

Notice on pilot of subsidy for private purchase of green vehicles

8/6/2012 Notice on expanding the pilot of demonstration and promotion of public hybrid buses

9/17/ Notice on subsequent promotion and application of 2013 green vehicles

Notice on adjusting the financial subsidies policies of promotion and application for green vehicles
Notice on further promotion and application of green vehicles

Notice on the financial incentive policy for the promotion and application of green vehicles from 2016 to 2020
Notice on further improving the fiscal subsidy policy for the promotion and application of new energy vehicles
Passenger vehicles and light commercial vehicles for public service, vehicles using hybrid energy, pure electric, and fuel cells may receive 50,000, 60,000, and 250,000 yuan, respectively. Urban public buses longer than $10 \mathrm{~m}$, buses using hybrid energy, and pure electric and fuel cells may receive $420,000,500,000$, and 600,000 yuan, respectively. For green vehicles satisfying the given criteria, the subsidy standard is 3,000 Yuan/kWh. The subsidies for plug-in hybrid passenger vehicle and pure electric passenger vehicles could be up to 50,000 and 60,000 yuan, respectively.

Depending on the fuel-saving rate, hybrid power system, and maximum electric power ratio, the subsidies range from 50,000 to 420,000 yuan.

Pure electric and plug-in hybrid passenger cars could receive subsidies ranging from 35,000 to 60,000 yuan. Buses could get a subsidy ranging from 250,000 to 500,000 yuan in accordance with the length, and another subsidy of 2,000 Yuan/kWh with a limit of 150,000 yuan depending on batteries. Fuel cell passenger vehicles and commercial vehicles may get 200,000 yuan and 500,000 yuan as subsidies, respectively. A back slope mechanism is applied, implying that the subsidy standards in 2014 and 2015 would be reduced by 10 and $20 \%$ on this basis.

The subsidy standard for green vehicles is adjusted downwards by 5 and 10\% in 2014 and 2015, respectively.

Pure electric passenger vehicles and plug-in hybrid passenger vehicles may receive a subsidy amount ranging from 25,000 to 55,000 yuan per vehicle. The subsidy for fuel cell vehicles ranges from 200,000 to 500,000 yuan. The subsidy standard for electric vehicles, plug-in hybrid vehicles, and other special vehicles and trucks is set at 1800 Yuan/kWh. A back slope mechanism is applied, from 2017 to 2020, except for fuel cell vehicles, subsidies for other types of vehicles would be reduced gradually, including a reduction of 20\% in 2017-2018 and another decline of 40\% in 2019-2020.

Raise the threshold standard with dynamic adjustment of recommended vehicle types. Under the premise of maintaining the overall stability of the subsidy policy from 2016 to 2020, the subsidy standard for green vehicles is adjusted as follows. For pure electric passenger vehicles, the subsidies are 20,000 yuan, 36,000, and 40,000 yuan in accordance to cruising mileage. Plug-in hybrid passenger vehicles may receive 24,000 yuan. Except for fuel cells, the subsidy standards for other types of vehicles reduces to $20 \%$ from 2019 to 2020 on the basis of current standards. New energy subsidies will be phased out one year ahead of schedule, and a transitional period of subsidies will be proposed for the first time; non-individuals will be required to drive $20,000 \mathrm{~km}$ instead of $30,000 \mathrm{~km}$ for new energy purchases; non-personal purchases of a new energy sales license can apply for a part of the subsidy fund, after reaching the mileage requirements of the full allocation Starting from 2019, for vehicles with operational mileage requirements, part of the fund will be allocated in advance upon completion of sales license, and the liquidation will be applied upon reaching the mileage requirements, that is, the "advance payment" mechanism will be proposed; local governments can continue to subsidize the purchase of new-energy buses

\section{Covered regions}

13 cities like Beijing, Shanghai and Chongqing and so on

Shanghai, Changchun, Shenzhen, Hangzhou, Hefei, Beijing

Winners in the bidding are responsible for the promotion in non-pilot cities.

Promote green vehicles relying on big cities.

39 city groups including 88 cities

Nationwide

Nationwide

Nationwide

Nationwide

(Continued on following page) 
TABLE 1 | (Continued) A summary of subsidy policies for green vehicles in China.

\begin{tabular}{|c|c|c|c|}
\hline $\begin{array}{l}\text { Issued } \\
\text { time }\end{array}$ & Document title & Subsidy criteria & Covered regions \\
\hline $\begin{array}{l}2020 / \\
4 / 23\end{array}$ & $\begin{array}{l}\text { Notice on further improving the fiscal subsidy policy for } \\
\text { the promotion and application of new energy vehicles }\end{array}$ & $\begin{array}{l}\text { New energy subsidies, which expire at the end of the year, } \\
\text { will be extended until 2022, with an annual limit of about } 2 \\
\text { million vehicles; support "vehicle electric separation" and } \\
\text { other new business models }\end{array}$ & Nationwide \\
\hline
\end{tabular}

arouses controversial discussions on the topic on whether the existing planning sufficiently matches the need for industrial development.

As an emerging industry, the development of electric vehicles depends on two key factors, namely market demand and technology innovation. The former is the foundation while the latter plays into the engineering required for the development required of electric vehicles. Only with the inherent market demand can we achieve a virtuous circle under the boost of technological innovation. Taking this into account, the incentive policy for green vehicles of China has gradually shifted from being technology-oriented to being market-oriented. On January 14, 2009, the State Council of China proposed a specific green vehicle strategy in the "Rejuvenation Plan for the Automotive Industry," arranging 10 billion Yuan to support the industrialization of green vehicles and related key components. Then, on January 23 of the same year, another document entitled "Circular on Launching Pilot Programs for Energy Conservation and Green Vehicles Demonstration and Promotion" was promulgated, clarifying that those purchasing green vehicles in pilot cities may receive fixed lump-sum subsidies from the central government. These two documents initiated the development of the green automotive industry, based upon subsidies. As shown in Table 1, seven national subsidy policies were issued from 2009 to 2020 .

The major trends of the varying subsidy policies for green vehicles could be summarized as follows. First, the sub-grades of subsidies depending on cruising mileage are more meticulous. Second, the criterion of energy density of battery increases. Third, banding subsidy policy that relies on the coefficient of energy dissipation becomes more popular. Two major considerations should be given; one is the objective of quality improvement and the other is the constraint of budget, resulting in the adjustment of subsidy policies. Notice that the subsidy for green vehicles tends to shrink with an expansion of covered regions and fields, indicating policy uncertainty for the producers and the market. For a traditional automotive producer, it takes at least 3-5 years to achieve mass production from design, while the accompanying strategic layout and planning requires 5-10 years. As an emerging industry, the time required from design to mass production for green the automotive industry is much longer than that for the traditional automotive industry. The incentive policies stimulate the development of the green automotive industry significantly, whereas the policy instability generates tremendous pressure for green vehicle producers. To maximize profits with these varying policies, some producers are prone to instant success with the $\mathrm{R} \& \mathrm{D}$ activities of green vehicles. One representative case is to obtain subsidies by shortening the product life cycle, i.e., promoting artificial green vehicles by installing a battery onto the internal-combustion engine or by tuning older electromobiles. Such "great leap forward" type of development would harm the sustainability of the green vehicle industry and be extremely wasteful in terms of governmental financial resources.

Aiming to consolidate the leading function of market mechanisms, the government decided to reduce the subsidy intensity as well as to raise the subsidy threshold for green vehicles in 2018. The latest subsidy policies introduced higher criteria in many aspects such as cruising mileage, battery life, charging efficiency, and sales price. More importantly, the two market-orientated policies, the green license plate policy and the double-credit policy, were introduced to stimulate the development of the green vehicle industry in China. Note that only green vehicles could satisfy the requirement of the green license plate policy to obtain the license plates painted in green, which implies quite a lot of extra benefits for buyers. Specifically, such extra benefits include: 1) reduced waiting time caused by purchase restrictions and a registration lottery; 2) avoiding the inconvenience of the application of odd-and-even license plate rules in some cities; 3 ) enjoying a purchase loan that accounts for up to $85 \%$ of the vehicle price; 4 ) enjoying free parking in some specific parking lots. As presented, the implementation of the incentive policy for green vehicles is undoubtedly a boon for potential consumers who worry about the expenditure of buying and driving a vehicle.

As green vehicles with green license plates become more popular in pilot cities, the green license plate policy has greatly stimulated consumers' desire to purchase green vehicles instead of traditional ones. Meanwhile, the document entitled "Measures for the Parallel Management of the Average Fuel Consumption and Integral for Green Vehicles of Passenger Vehicle Enterprises" that was published on September 28, 2017, forces vehicle producers to gradually switch to clean energy. In comparison, European countries mainly adopt the integral policy depending on the average fuel consumption of passenger vehicles, while in California in the United States, the integral policy of green vehicles is applied. As the largest auto market in the world, China has introduced both integral policies in parallel with promoting the development of the green automotive industry. In practice, the management and assessment of the two policies are separate. The only link between them lies in the integral deduction, i.e., a negative integral yielded by average fuel consumption that could be deducted by a positive integral of green vehicles, whereas the sole way to remove a negative integral of green vehicles is to buy a 
positive one. The Chinese government plans to cancel all subsidies for green vehicles by 2020, while the calculation parameters of CAFT would decrease gradually during this period. It is rational to forecast that auto producers have to face greater emission reduction pressure because of the policy variation. Inevitably, investing more in green vehicles would become a more important alternative strategic direction for most auto producers.

\section{CONCLUDING REMARKS}

To improve the positive effects of green vehicles on energy conservation and emission reduction, China has gradually shifted from being government-oriented to being marketoriented in the policy formulating the process of the green automotive industry. In the coming development stages of the green automotive industry, advanced clean technologies and lowemission incentives may play key functions. It is expected that the introduction and implementation of the two policies could achieve objectives on emission reduction as well as the improved development of green vehicles in the near future.

In addition, at the micro level, the government should pay more attention to the construction of charging and changing the infrastructure for new energy vehicles. Charging and changing infrastructure is a very important key link in the development of new energy vehicles and is also important in supporting the promotion of the new energy vehicles industry. In recent years, the National Development and Reform Commission, the National Energy Administration, the Ministry of Industry and Information Technology, and other departments have introduced a series of policies and measures, which have effectively promoted the construction of China's charging and changing infrastructure. However, China still faces many problems in the construction of charging and changing power facilities. The main reason is that in some old residential areas with large population densities it is difficult to construct charging and electricity exchange facilities due to the insufficient carrying capacity of the power system. In addition,

\section{REFERENCES}

He, K., Huo, H., Zhang, Q., He, D., An, F., Wang, M., et al. (2005). Oil Consumption and CO2 Emissions in China's Road Transport: Current Status, Future Trends, and Policy Implications. Energy Policy 33 (12), 1499-1507. doi:10.1016/j.enpol.2004.01.007

Huo, H., and Wang, M. (2012). Modeling Future Vehicle Sales and Stock in China. Energy Policy 43, 17-29. doi:10.1016/j.enpol.2011.09.063

International Energy Agency (2015). $\mathrm{CO}_{2}$ Emissions from Fuel Combustion Highlights. https://www.iea.org/publications/freepublications/publication/ co2-emissions-from-fuel-combustion-highlights-2015.html. Accessed June 22, 2017.

Wu, Y., Zhang, S. J., Hao, J. M., Liu, H., Wu, X., Hu, J., et al. (2017). OnRoad Vehicle Emissions and Their Control in China: A Review and Outlook. Sci. Total Environ. 574 (1), 332-349. doi:10.1016/j.scitotenv. 2016.09 .040 some consumers or residents have raised objections to the construction of charging piles because of concerns about safety. Therefore, in the future transformation of older urban areas in China, the transformation of the electric power system will become a particularly important driving force to promote the development of the new energy vehicle industry.

\section{AUTHOR CONTRIBUTIONS}

L-SQ: Conceptualization, Data curation, Formal analysis, Writing-review and editing. D-XY: Formal analysis, Funding acquisition, Investigation, Methodology, Project administration, Writing-review and editing. K-RH: Manuscript revision/review, Funding acquisition, W-PW: Formal analysis, Investigation, Project administration, Resources, Software. W-KZ: Investigation, original draft.

\section{FUNDING}

This work is partially supported by the National Natural Science Foundation of China (71771057,72003044,72003045,71903056), National Social Science Foundation of China(20FGLB072), Natural Science Foundation of Hunan Province (2020JJ5111, 2020JJ5104), Project of Hunan Social Science Achievement Appraisal Committee (XSP20YBZ081), Youth Innovation Driven Project of Hunan University of Technology and Bussiness (19QD04), Guangdong Social Science Project (GD20SQ15), Guangzhou Social Science Project (2020GZQN39), the Foundation for High-level Talents in Higher Education of Guangdong, GDUPS (2019), National Science Foundation for Post-doctoral Scientists of China (2020M672464), MOE (Ministry of Education in China) Project of Humanities and Social Sciences (19YJC790154), Philosophy and Social Science Foundation of Hunan Province in China (18YBQ075), and Research and Innovation Project for Graduate Students in Hunan Province (CX20201083).

Yan, X., and Crookes, R. J. (2009). Reduction Potentials of Energy Demand and GHG Emissions in China's Road Transport Sector. Energy Policy 37 (2), 658-668. doi:10.1016/j.enpol.2008.10.008

Conflict of Interest: The authors declare that the research was conducted in the absence of any commercial or financial relationships that could be construed as a potential conflict of interest.

The reviewer (YF) declared a shared affiliation with one of the authors, (LQ), to the handling editor at time of review.

Copyright (c) 2021 Qiu, Yang, Hong, Wu and Zeng. This is an open-access article distributed under the terms of the Creative Commons Attribution License (CC BY). The use, distribution or reproduction in other forums is permitted, provided the original author(s) and the copyright owner(s) are credited and that the original publication in this journal is cited, in accordance with accepted academic practice. No use, distribution or reproduction is permitted which does not comply with these terms. 